\title{
Time Course of Fos-Like Immunoreactivity Associated with Cholinergically Induced REM Sleep
}

\author{
Priyattam J. Shiromani, Munazza Malik, Stuart Winston, and Robert W. McCarley \\ VA Medical Center and Harvard Medical School, Brockton, Massachusetts 02401
}

\begin{abstract}
Now that the pharmacology and neuronal connectivity underlying REM sleep is beginning to be understood, it is important to begin investigations that elucidate the transcriptional response related to the REM sleep process. The present study focuses on determining the temporal development of Fos-like immunoreactivity (Fos-LI) in the dorsolateral pons following cholinergically induced, sustained rapid eye movement (REMc) sleep in cats. Microinjections $(0.25 \mu \mathrm{l})$ of vehicle $(n=3)$ or carbachol $(0.2-4.0 \mu \mathrm{g} / 0.25 \mu \mathrm{l})$ were made into the medial pontine reticular formation. Carbachol produced a state with all the signs of natural REM sleep, and with durations from 0 min to $120 \mathrm{~min}$. Animals were killed either immedlately or at varlous intervals after the end of REMc. Compared to vehicle- and carbacholtreated animals without REMc, the animals with REMc showed a significantly higher number of Fos-LI cells in pontine regions that have been implicated in REM sleep generation. Regions with REMc-associated Fos-LI increases included the lateral dorsal tegmental (LDT) and pedunculopontine tegmental (PPT) nuclei; the locus coeruleus; the dorsal raphe; and the medial pontine reticular formation. More Fos-LI cells were found with longer REMc bouts than with shorter-duration REMc bouts. However, with 2 hr long REMc bouts the number of Fos-LI cells returned to control levels, suggesting that the c-fos transcriptional cascade is turned off once a threshold of REMc has been reached. These findings indicate that pontine neuronal populations implicated in REM sleep express more c-fos in the course of REMc, and that the extent of expression is related to the duration of the state.
\end{abstract}

[Key words: c-fos, immediate-early genes, REM sleep, brainstem, $\mathrm{ACh}]$

Considerable progress has been made in understanding the physiology, pharmacology, and neuronal mechanisms subserving REM sleep. Lesion and transection studies have shown that REM sleep originates from within the pons, and neuronal activity in this region shows a pattern of discharge that is specifically related to REM sleep (summarized in Steriade and McCarley, 1990). For instance, during REM sleep locus coeruleus and dorsal raphe cells become virtually silent (McGinty and Harper, 1976; Hobson et al., 1975). On the other hand, a subpopulation

Received Sept. 1, 1994; revised Nov. 4, 1994; acecpted Nov. 22, 1994

This work was supported by grants from the DVA Medical Research Service and NIH NS30140 (P.J.S.).

Correspondence should be addressed to P. J. Shiromani, VA Medical Center and Harvard Medical School, 940 Belmont Street, Brockton, MA 02401.

Copyright 1995 Society for Neuroscience $0270-6474 / 95 / 153500-09 \$ 05.00 / 0$ of cholinergic cells in the lateral dorsal tegmental (LDT) and pedunculopontine tegmental (PPT) nuclei (El Mansari et al., 1989; Kayama et al., 1992; Steriade et al., 1990b), as well as presumptive effector neurons in the medial pontine reticular formation (medial PRF) increase discharge rates (summarized in Steriade and McCarley, 1990). It is hypothesized that REM sleep is generated as a result of a coordinated interaction between these neuronal groups (summarized in Steriade and McCarley, 1990).

Investigators have now begun to examine transcriptional responses associated with REM sleep because such events could provide insight into the functional relevance of the periodic brain activation during REM sleep. The initial focus of these efforts has been on the expression of the immediate-early gene (IEG) c-fos during REM sleep. IEGs such as $c$-fos have been found to be rapidly and transiently expressed in cells in response to cellular stimulation (Morgan et al., 1989; Sheng and Greenberg, 1990; Sagar et al., 1993). These genes encode proteins that bind to a recognition site on a target gene and promote its expression (Chiu et al., 1988; Franza et al., 1988; Landschulz et al., 1988; Gentz et al., 1989; Turner et al., 1989). There is a growing body of evidence to suggest that such transcriptional cascades can modify responsivity of the cell to subsequent input and/or influence neuronal plasticity (Sheng and Greenberg, 1990).

In order to determine whether such cascades are triggered during sleep, $c$-fos expression has been examined in association with pharmacologically induced REM sleep (Shiromani et al., 1992; Yamuy et al., 1993). Pontine cholinergic mechanisms are hypothesized to be the final effector pathways in REM sleep generation (summarized in Shiromani et al., 1987). Therefore, microinjection of cholinergic agonists, for example, carbachol, into the medial pontine reticular formation readily triggers a behavioral state that is indistinguishable from natural REM sleep (George et al., 1964; Baghdoyan et al., 1984; Velazquez-Moctezuma et al., 1989). Such pharmacological stimulations produce a sustained REM sleep-like state and in this way one can exclude the possibility of $c$-fos induction by intervening episodes of non-REM sleep or waking. Recently, we found $c$ fos expression, as determined by the presence of the c-fos protein Fos, in dorsolateral pontine areas during cholinergically induced REM sleep (Shiromani et al., 1992). Yamuy et al. (1993) found that medullary regions that relay the descending signals associated with REM sleep, such as atonia, also showed Fos-like immunoreactivity (Fos-LI) during cholinergically induced REM sleep. Mcrchant-Nancy et al. (1992) have shown c-fos expresśion, in rats, in pontine neurons in association with auditory manipulations that prolong REM sleep. These studies show IEG expression in discrete pontine nuclei following manipulations that augment REM sleep. 
A. Controls

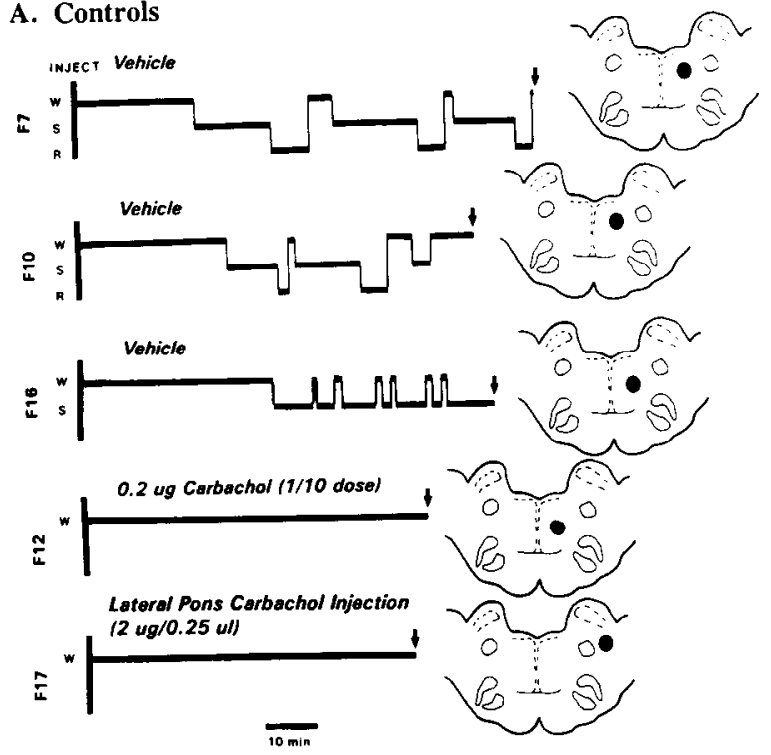

B. Development of Fos-LI: Vary the Duration of REMc

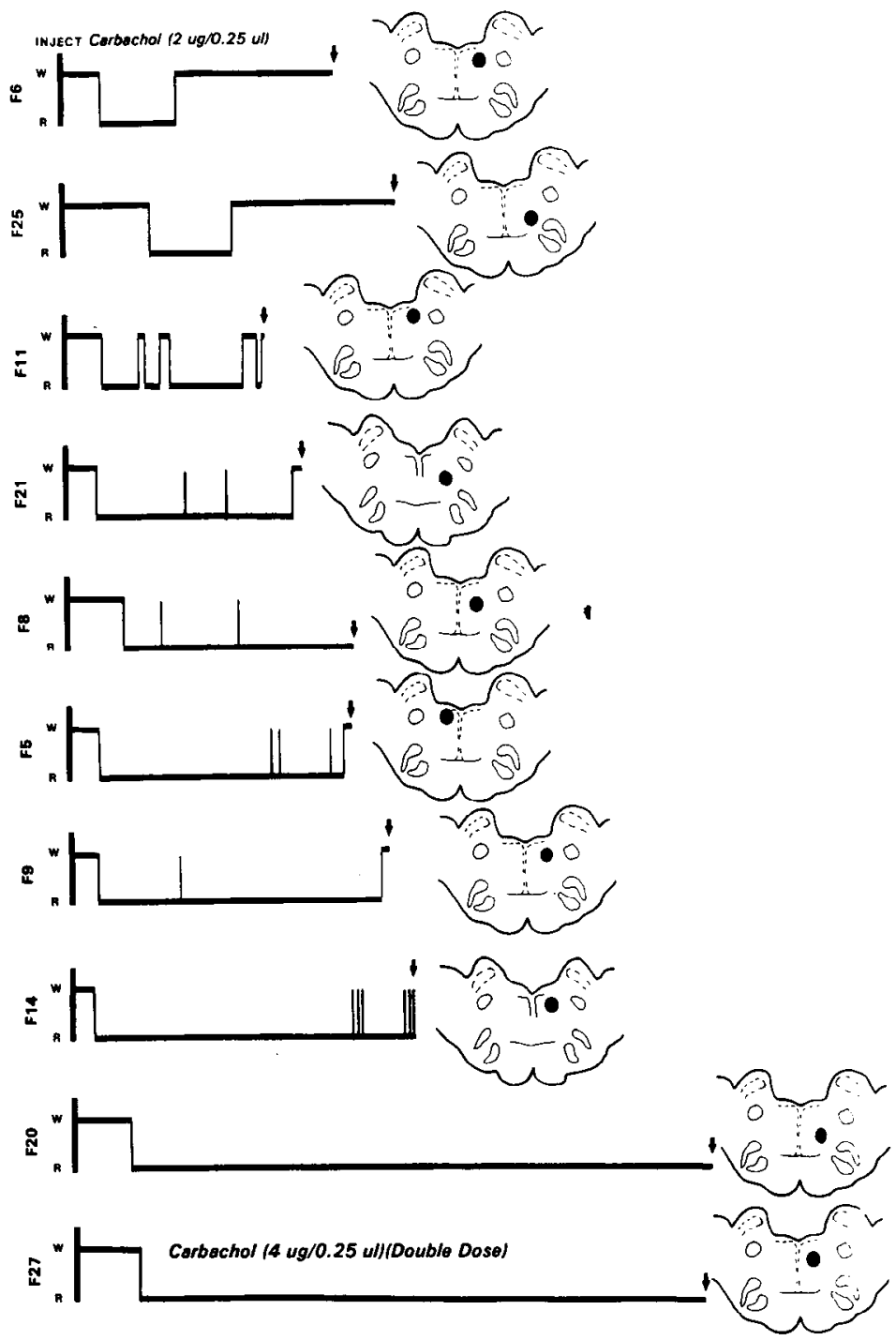

Figure 1. Schematic representation of sleep-wake patterns in animals given vehicle or carbachol microinjections. Arrows represent the time point where the animals were administered Nembutal and killed. The histological verification of the injection site in the pons is also depicted. The hypnograms depict the three sleep-wake states ( $W$, wake; $S$, slow-wave sleep; $R$, REM sleep or REMc).

The purpose of the present study was to determine the time course of $c$-fos expression in specitic pontine neuronal populations in response to varying durations of cholinergically induced REM sleep.

\section{Materials and Methods}

Subjects and surgical procedures. Fifteen adult cats weighing $3-5 \mathrm{~kg}$ were used. The cat was chosen because the pharmacology and neuronal network subserving REM sleep has been most extensively studied in this species. Under Nembutal anesthesia $(35 \mathrm{mg} / \mathrm{kg}$, i.v.) and using sterile surgical procedures, the cats were chronically implanted with a standard set of electrodes for recording the electroencephalogram, electromyogram, electro-oculogram, and ponto-geniculo-occipital (PGO) spikes. A stainless steel guide cannula (24 gauge) with a stylette (31 gauge) was implanted in the medial pontine reticular formation (medial PRF) area where cholinergic stimulation reliably produces a sustained REM sleep-like episode (REMc) [target: P 3.0, L 1.8, $\mathrm{H}-4.5, \theta 40^{\circ}$, according to Berman's (1968) stereotaxic atlas]. Histological localization of the cannula tips in the medial PRF is depicted in Figure 1.

Experimental procedures. Two weeks after recovery from surgery, all cats were given a week of adaptation to the recording conditions and chamber so as to avoid stress associated with handling and unfa- miliarity with the sleep-recording environment. The adaptation procedure consisted of the cxperimenter placing cach cat in a cat-restraining bag, sitting for $5 \mathrm{~min}$ with the bag in the lap, withdrawing and reinserting the stylette in the guide cannula, and, after an additional minute, releasing the cat from the bag into the sleep-recording chamber This chamber was a well ventilated, sound attenuated box $(62 \times 62 \times$ $92 \mathrm{~cm})$ maintained at room temperature $\left(23^{\circ} \mathrm{C}\right)$ with food, water, and a litter box. The cats were returned to the vivarium after $3 \mathrm{hr}$ in the sleeprecording chamber. During some adaptation sessions, sleep recordings were obtained for $2 \mathrm{hr}$ in order to examine the patency and integrity of the EEG recording electrodes, cable, and polygraph. The adaptation procedure was followed daily for a week, and the experimental sessions matched the adaptation sessions. All adaptation sessions and experiments were begun at about 10:00 hr.

In all cats, vehicle $(0.9 \%$ saline $)$, or carbachol microinjections were made with a Hamilton microliter syringe attached via polyethylene tubing to a 31 gauge stainless steel cannula that extended $1 \mathrm{~mm}$ beyond the guide cannula. A total volume of $0.25 \mu \mathrm{l}$ was slowly and continuously injected. The infusion cannula was left in place for $1 \mathrm{~min}$ and then withdrawn and the stylette reinserted. Immediately thereafter, the cats were gently released from the restraining bag into the sleep-recording chamber and polygraphic sleep recordings were made.

In all cats, the polygraphic records were monitored for signs of REM 
Table 1. Summary of the changes in REM sleep parameters (in minutes) and time to death (minutes) following carbachol or vehicle microinjections

Vehicle and carbachol controls

\begin{tabular}{|c|c|c|c|c|c|c|c|c|c|}
\hline \multicolumn{5}{|c|}{ Vehicle and carbachol controls } & \multicolumn{5}{|c|}{ Development of FOS-LI } \\
\hline $\begin{array}{l}\text { Animal } \\
\text { ID }\end{array}$ & $\begin{array}{l}\text { Total } \\
\text { REM } \\
\text { sleep } \\
\text { time }\end{array}$ & $\begin{array}{l}\text { REM } \\
\text { sleep } \\
\text { latency }\end{array}$ & $\begin{array}{l}\text { Time to } \\
\text { death } \\
\text { after } \\
\text { end of } \\
\text { REM } \\
\text { sleep } \\
\end{array}$ & $\begin{array}{l}\text { Total } \\
\text { elapsed } \\
\text { time } \\
\text { after } \\
\text { microin- } \\
\text { jection } \\
\text { until } \\
\text { death } \\
\end{array}$ & $\begin{array}{l}\text { Animal } \\
\text { ID }\end{array}$ & $\begin{array}{l}\text { REMc } \\
\text { duration }\end{array}$ & $\begin{array}{l}\text { Latency } \\
\text { to REMc }\end{array}$ & $\begin{array}{l}\text { Time to } \\
\text { death } \\
\text { after } \\
\text { end of } \\
\text { REMc }\end{array}$ & $\begin{array}{l}\text { Total } \\
\text { elapsed } \\
\text { time } \\
\text { after } \\
\text { microin- } \\
\text { jection } \\
\text { until } \\
\text { death } \\
\end{array}$ \\
\hline F7 & 15.8 & 37.2 & 0.8 & 87.7 & F6 & 15.2 & 7.5 & 32.7 & 55.4 \\
\hline F10 & 7.2 & 37.5 & 17.5 & 76.2 & $\mathrm{~F} 25$ & 16.5 & 17.4 & 34 & 67.9 \\
\hline F16 & 0 & NA & NA & 79 & F11 & 27 & 7 & 0.6 & 39.6 \\
\hline $\mathrm{F} 12$ & 0 & NA & $\mathrm{NA}$ & 65.6 & $\mathrm{~F} 21$ & 39.1 & 5.4 & 1.9 & 48 \\
\hline \multirow[t]{6}{*}{ F17 } & 0 & NA & NA & 63 & $\mathrm{~F} 8$ & 45.5 & 10.8 & 0.1 & 58.3 \\
\hline & & & & & $\Gamma 5$ & 49 & 5.5 & 1.3 & 57.7 \\
\hline & & & & & F9 & 57.8 & 4.8 & 1.5 & 64.8 \\
\hline & & & & & F14 & 62.7 & 3.43 & 0.4 & 69.9 \\
\hline & & & & & F20 & 119.8 & 11.5 & 0.1 & 131.3 \\
\hline & & & & & F27 & 116 & 13.3 & 0.1 & 129.3 \\
\hline
\end{tabular}

sleep, which included cortical EEG desynchronization, muscle atonia, PGO spikes, and rapid eye movements. In all cats, the end of REM sleep was defined as the resumption of muscle tone for $2 \mathrm{~min}$ or longer. In all animals the experimenter did not terminate REMc; rather, the animals spontaneously exited from REMc and were killed by an overdose of Nembutal (intravenous) at appropriate intervals after the end of the REMc bout (schematically depicted in Fig. 1). The time from injection of Nembutal to perfusion was about $8 \mathrm{~min}$ in all cats.

Immunohistochemistry. All brains were perfused via the ascending aorta with $300 \mathrm{ml}$ of ice-cold $0.9 \%$ saline followed by $2 \%$ formaldehyde in $0.1 \mathrm{M}$ phosphate buffer. The brains were blocked and placed overnight in the fixative and then transferred to $15 \%$ sucrose $/ 0.1 \mathrm{~m}$ phosphate buffer until equilibration. The pontine brainstem was cut at a thickness of $40 \mu \mathrm{m}$ on a freezing microtome and one-in-four series (160 $\mu \mathrm{m}$ intervals) of sections were processed for Fos immunohistochemistry using the avidin-biotin procedure with 3,3'-diaminobenzidine (DAB) as the chromogen. A polyclonal antibody against the $\mathrm{N}$-terminal peptide 4-17 of the Fos protein was used (sheep anti-Fos, Cambridge Research Biochemicals) at a dilution of 1:2000. The brains from each animal were processed separately, and to distinguish between specific and non specific immunoreactivity, some test sections were not incubated in the antibody.

Data analysis. Counts of Fos-LI cells were made in the pontine regions that have been implicated in REM sleep generation. These regions include the cholinergic zone of the lateral dorsal tegmental (LDT) and the pedunculopontine tegmental (PPT) nuclei, the noradrenergic zone of the locus coeruleus (LC), the serotonergic zone of the dorsal raphe, and the medial PRF cells. The monoaminergic and cholinergic cell groups were delineated from our published atlas (Shiromani et al., 1988) and also from our recent study where we have used triplelabeling techniques to visualize cholinergic, noradrenergic (anti-dopamine- $\beta$ hydroxylase), and serotonergic somata in the same section (Shiromani et al., 1992). Fos-LI cells, clearly visible because of the nuclear staining, were plotted using a computer-based camera lucida system (MicroBrightfield, VT). Counts of Fos-LI-positive cells were made from the side ipsilateral and contralateral to the microinjection site. However, in the medial PRF, counts were made from the contralateral side only. The ipsilateral side was not counted so as to exclude the possibility of counting Fos-LI cells that might have resulted from the injury due to the cannula insertion. The regional expression of Fos-LI was determined without knowledge of vehicle, drug, or length of REMc. For each animal, counts of Fos-LI cells were obtained from every eighth $40 \mu \mathrm{m}$ section, and on average 12 sections were counted.

The animals were divided on the basis of vehicle versus carbachol, and in the carbachol-treated animals further grouping was based on the duration of sustained REMc bouts. The following six groups were formed: vehicle $(n=3)$; carbachol controls, 0 min REMc $(n=2)$; $1-$
25 min REMc $(n=2)$; $26-50$ min REMc $(n=4)$; $51-75$ min REMc $(n=2)$; and 101-125 min REMc $(n=2)$. The presence of overall differences was evaluated using a one-way ANOVA. Subsequently, pairwise post hoc comparisons were made using Dunnett's (pairwise comparisons against controls), or Neuman-Keul's (multiple pairwise comparisons) tests. Counts of Fos-LI cells at the P2 level from five animals (F5, F6, F7, F9, and F10) were published previously as a preliminary report (Shiromani et al., 1992). In that study, only a small portion of the pons (only P2 level) was assessed for Fos-LI and the dorsal raphe was not counted.

\section{Results}

Figure 1 and Table 1 show the sleep-wake profile in all animals in the study. Figure $1 A$ schematically depicts the sleep-wake states in cats receiving vehicle and control carbachol microinjections. Iwo of the three vehicle-injected animals had spontaneous episodes of REM sleep, but these bouts were interrupted by long bouts of waking and non-REM sleep. Two additional controls were used with manipulation of either the site of microinjection or dose of drug. One carbachol control animal (F17) received a microinjection of carbachol $(2 \mu \mathrm{g} / 0.25 \mu \mathrm{l})$ in an area lateral to the medial PRF. This animal did not have REMc but remained in quiet wakefulness and was killed $63 \mathrm{~min}$ after the microinjection. Another animal (F12) received a $1 / 10$ the dose of carbachol $(0.2 \mu \mathrm{g} / 0.25 \mu \mathrm{l})$ into the medial PRF where higher dose of carbachol produced REMc. This animal did not enter into REMc but also remained in quiet wakefulness and was killed $65.6 \mathrm{~min}$ after the microinjection. There were no significant differences (independent $t$ test $=0.936$ ) in the number of Fos-LI cells between the vehicle control and carbachol control animals and, therefore, the data from these animals was combined to form one control group.

Figure $1 B$ summarizes the sleep-wake states in animals that received $2 \mu \mathrm{g} / 0.25 \mu \mathrm{l}(n-9)$ or $4 \mu \mathrm{g} / 0.25 \mu \mathrm{l}(n=1)$ of carbachol into the medial PRF. These animals entered into REMc with an average latency of $8.66( \pm 1.48)$ min (range, 3.43-17.4 $\mathrm{min}$ ) after the microinjection. These animals were killed either immediately or at various intervals after the end of the REMc bout (see Fig. $1 B$, Table 1). To confirm the effects of a $2 \mathrm{hr}$ long REMc bout obtained in one animal that received 2.0 
Vehicle
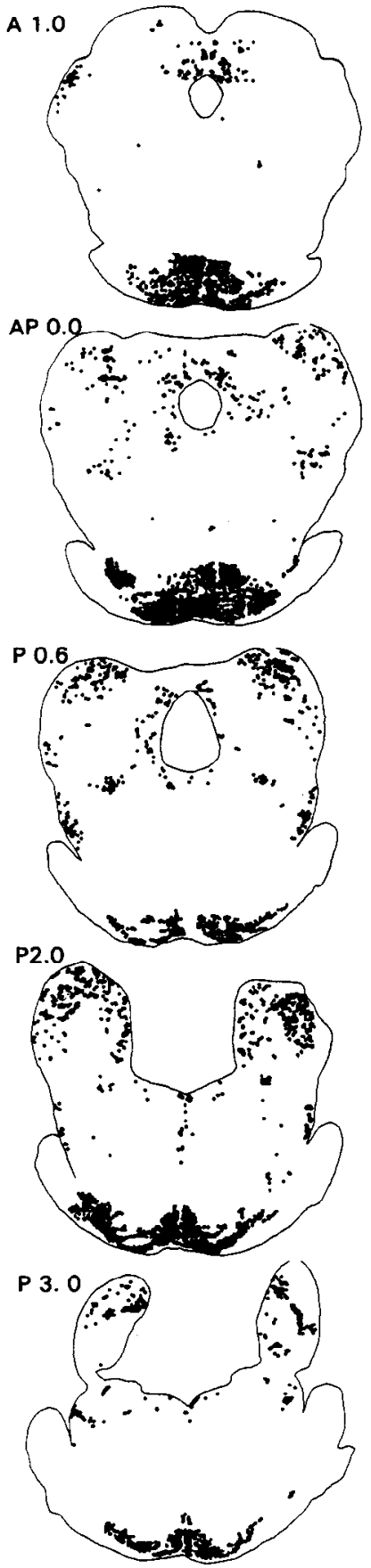

Carbachol
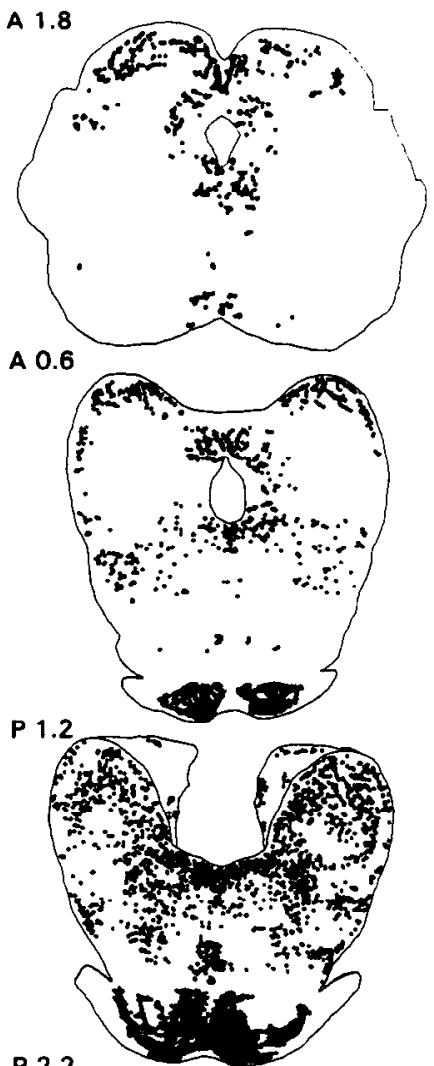

P 2.2

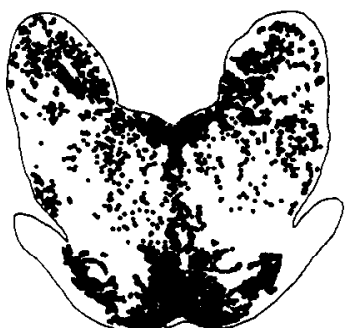

P 3.3

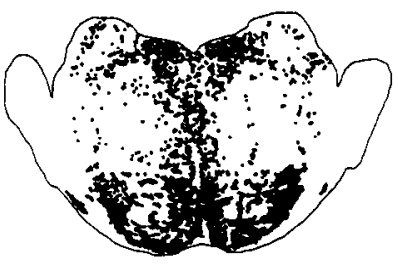

Figure 2. Schematic distribution of Fos-LI cells in the pons in one each representative vehicle $(\mathrm{F} 16)$ and REMc (F11) animal. The numbers refer to the anterior-posterior plane as defined by Berman (Berman, 1968). $\mu \mathrm{g} / 0.25 \mu \mathrm{l}$ of carbachol, one animal was given a higher dose of carbachol $(4.0 \mu \mathrm{g} / 0.25 \mu \mathrm{l})$. This also produced a $2 \mathrm{hr}$ long REMc bout.

\section{Time course of Fos-LI in response to length of REMC}

To determine the relationship between Fos-LI and REMc duration, microinjections of carbachol were made into the medial PRF area and the animals killed immediately upon termination of the REMc bout. However, with short REMc (i.e., $15 \mathrm{~min}$ duration) the animals were left undisturbed for an additional 30 min to permit synthesis of the Fos protein (see Fig. 1B, Table 1). Moreover, the vehicle and carbachol control animals were killed $60-90 \mathrm{~min}$ after microinjection. This is the time period when peak numbers of Fos-LI cells have been shown to occur in another experimental paradigm (Giovannelli et al., 1992).

In all animals, counts of Fos-LI cells were made from the side ipsilateral and contralateral to the microinjection site. There was no significant difference in the number of Fos-LI cells between the ipsilateral versus contralateral sides $(t=1.08$; $\mathrm{df}=14)$. Figure 2 shows a schematic representation of the distribution of Fos-LI in one vehicle and one carbachol animal with long-duration REMc. Figure 3 shows photomicrographs of Fos-LI cells in the dorsolateral pons in vehicle and REMc animals.

Figure 4 depicts the number of Fos-LI cells in the LDT, PPT, 

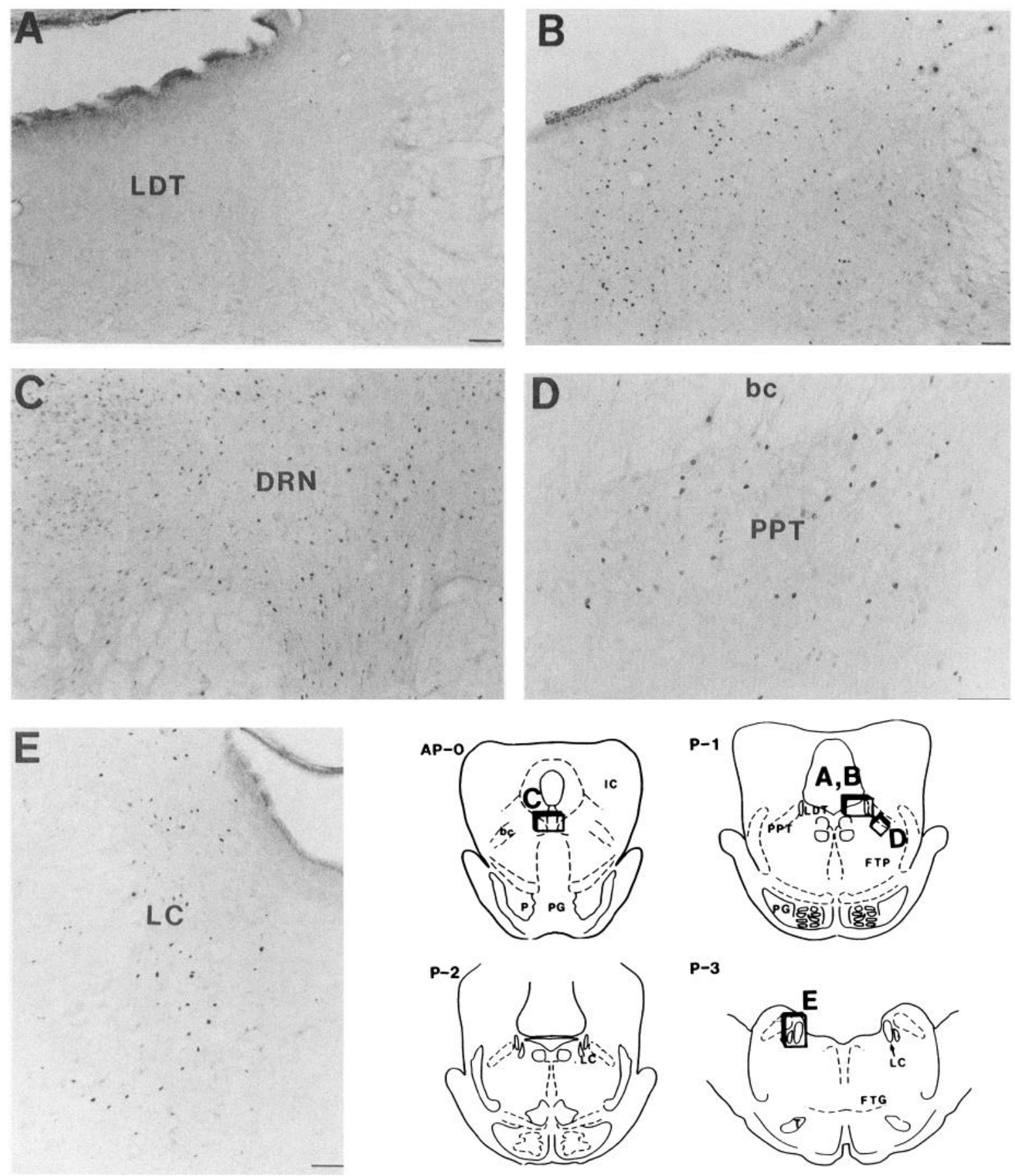

Figure 3. Photomicrographs of Fos-LI cells in the dorsolateral pons in one vehicle $(A)$ and REMc animals. The schematic diagrams identify the location of the photomicrographs. Fos is a nuclear protein and therefore the stained nuclei are visible as round to oval shaped. Often the nucleolus is spared. $b c$, brachium conjunctivum; FTG, gigantocellular tegmental field; FTP, paralemniscal tegmental field; $I C$, inferior colliculus; $L C$, locus coeruleus; $L D T$, lateral dorsal tegmental nucleus; $P P T$, pedunculopontine tegmental nucleus; $D R N$, dorsal raphe nucleus. Scale bar, $100 \mu \mathrm{m}$.

dorsal raphe, and LC in all animals in the study. For purposes of data analysis the animals were grouped as described previously. Compared to vehicle and carbachol controls (low dose and lateral site injection animals), the animals with REMc showed a significant increase in the number of Fos-LI cells $[F(4,14)=57.5 ; P<0.0001]$. Furthermore, the number of FosLI cells was related to the duration of $\operatorname{REMc}[F(4,11)=34.4$; $P<0.0001]$. With $16 \mathrm{~min}$ of REMc, the number of Fos-LI cells was significantly higher compared to vehicle and carbachol con- trols $(P<0.05)$. With $26-50$ min REMc, the number of Fos-LI cells was higher compared to vehicle and carbachol controls, and compared to 16 min REMc $(P<0.05)$. The animals with $60 \mathrm{~min}$ of undisturbed REMc had more Fos-LI cells compared to animals with shorter- or longer-duration REMc bouts $(P<$ $0.05)$. However, if REMc persisted for $2 \mathrm{hr}$, then the number of Fos-LI cells was not significantly different compared to controls or compared to animals with 16 min REMc. A third order polynomial was found to express this relationship $(F=5.96 ; P<$ 


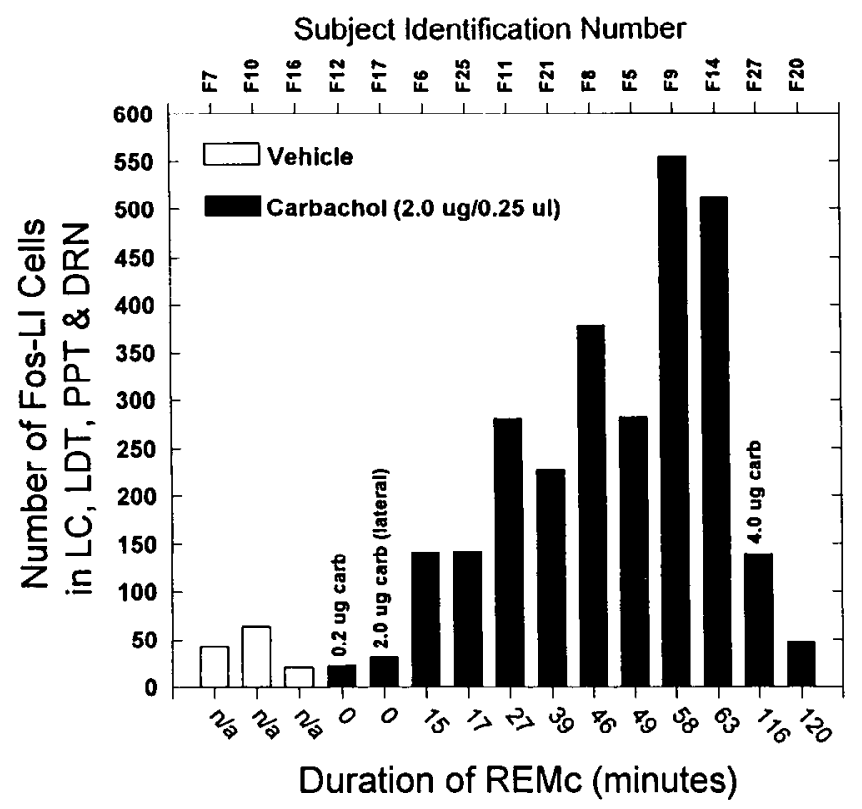

Figure 4. Development of Fos-LI in response to duration of REMc. The counts represent total number of Fos-LI cells in the LDT, PPT, LC, and dorsal raphe. The figure summarizes the data from all animals in the study. The subject identification number is given in the top axis.

$0.04 ; Y=40.9+2.59 X+0.177 X^{2}-0.00166 X^{3} ; Y=$ number of Fos-LI cells; $X=$ length of REMc).

Figure 5 indicates that the changes in Fos-LI were not related to the elapsed time from microinjection. For example, the two carbachol controls that did not have REMc were measured at a similar point in time; that is, 60-70 min after microinjection, compared to two animals with about $1 \mathrm{hr}$ long REMc. The animals with REMc showed Fos-LI while the carbachol controls did not. Similarly, two animals with 15-16 min of REMc were examined at a point in time similar to animals with longer REMc bouts. However, the animals with the shorter REMc bouts had significantly fewer number of Fos-LI cells compared to animals with $1 \mathrm{hr}$ long REMc bouts $(P<0.05)$.

Figure 6 depicts the number of Fos-LI cells in the LC, dorsal raphe, LDT, and PPT following REMc. This breakdown was done in order to determine whether there were differences in the time course of Fos-LI in these areas. All four neuronal areas showed an increase in the number of Fos-LI cells in response to REMc, with the LDT area showing the greatest number of Fos-LI cells compared to the other three areas $(F=21.75$; df $=1,17 ; P<0.001$ ). In all four areas the number of Fos-LI cells declined after $2 \mathrm{hr}$ continuous REMc.

Aside from the monoaminergic/cholinergic areas, another area in the pons that was examined in detail was the medial PRF. This is the area from which cholinergic agonists readily induce REMc. The microinjections were made in the medial PRF and the site of the injection typically showed a high level of Fos-LI cells in all animals. Some of these cells were found to be GFAP (glial fibrillary acidic protein, a putative marker of glial cells) positive, suggesting the induction of $c$-fos in response to injury resulting from the cannula insertion. Counts of Fos-LI cells were made in the medial PRF area contralateral to the microinjection site. The ipsilateral side was not counted because high levels of Fos-LI were seen in all animals and this may be in response to injury resulting from the cannula insertion. Figure 7 summarizes the results of the number of Fos-LI cells in the contralateral medial PRF. Generally, the number of Fos-LI cells were fewer compared to the LDT/PPT, LC, and dorsal raphe. However, the time course of Fos-LI was similar to the other groups.

\section{Fos-LI in other brain regions}

Many brain regions showed some Fos-LI cells regardless of treatment. For instance, the ventral pontine area showed numerous Fos-LI cells in all animals. Specific counts of Fos-LI cells in these and other regions were not obtained because no obvious difference, based on a visual inspection, related to the various treatments was found to occur. However, we cannot rule out the possibility that subtle changes in the number of Fos-LI cells related to REMc could have occurred in these regions.

Particular emphasis was placed on regions implicated in generating the tonic and phasic aspects of REM sleep. For instance, $\theta$ activity is recorded during REM sleep and during some purposeful behaviors in the hippocampus (Winson, 1972). There were no clearly evident differences in the number of Fos-LI cells

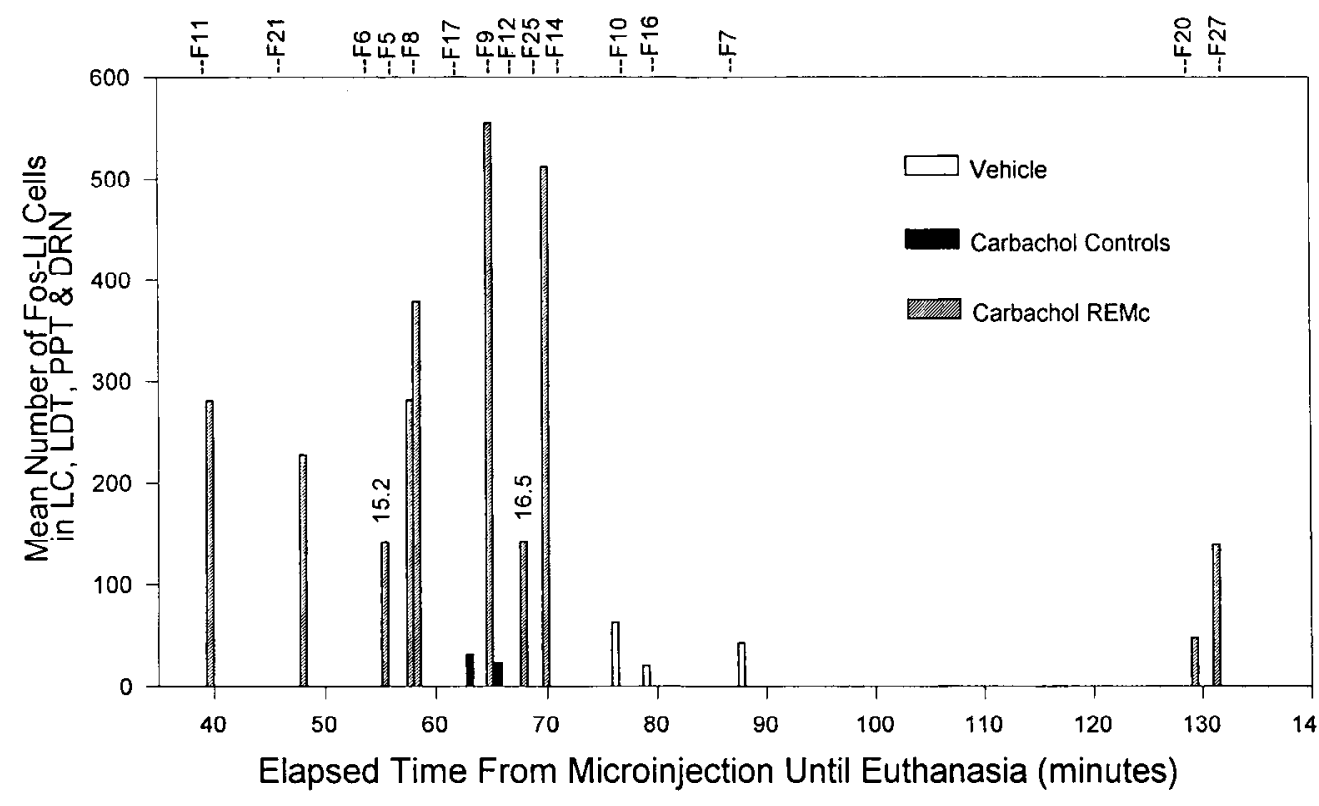

Figure 5. Same data as in Figure 4 but in this figure the data are plotted as a function of elapsed time from microinjection of drug or vehicle. Vehicle and carbachol control animals were examined at the time point when peak levels of Fos-LI were expected, based on evidence from another experimental manipulation (Giovannelli et al., 1992). The number of Fos-LI cells was not influenced by the elapsed time from the microinjection. Rather, a higher number of Fos-LI cells occurred in conjunction with REMc. The subject identification number is given in the top axis. 
Figure 6. Number of Fos-LI cells in the LDT, PPT, dorsal raphe, and LC. A schematic distribution of Fos-LI cells in a representative vehicle and REMc animal is shown in Figure 2. Asterisks indicate significant difference compared to vehicle and carbachol controls $(P<0.05)$
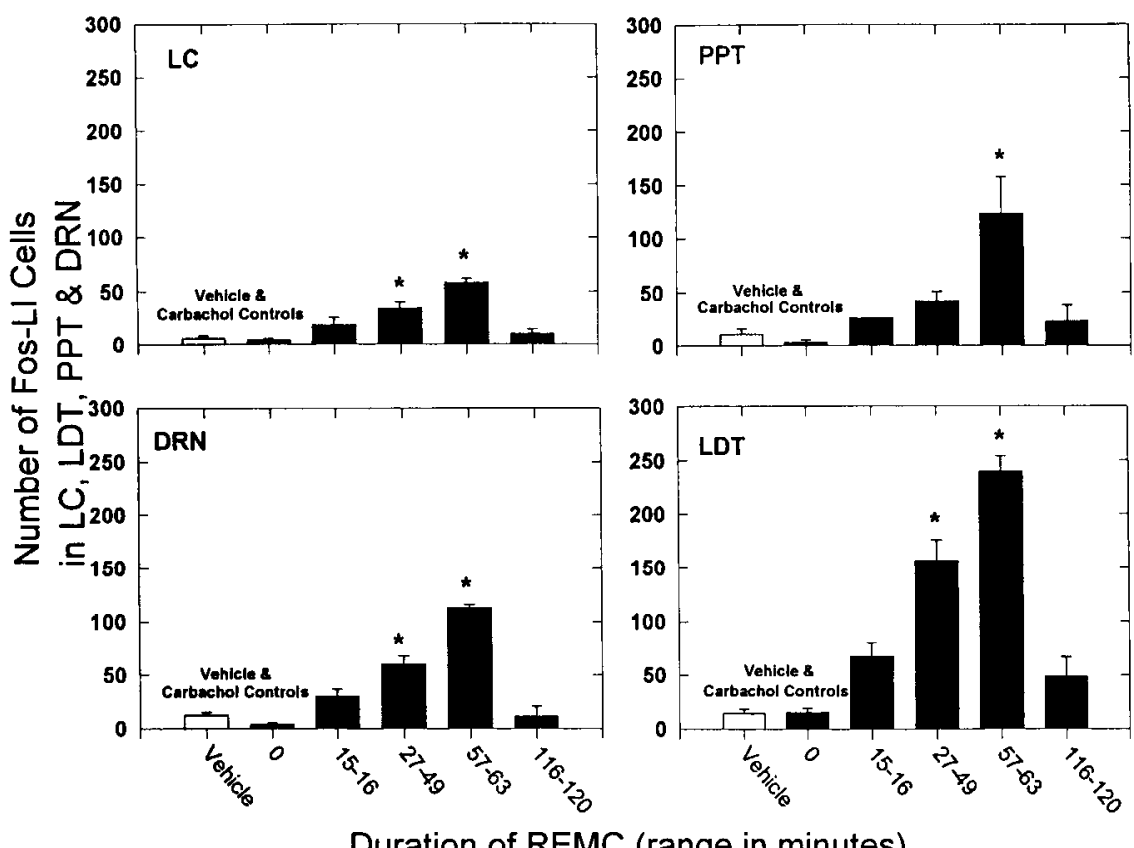

Duration of REMC (range in minutes) in the various hippocampal fields and the dentate gyrus in the vehicle versus animals with REMc. Similarly, we could not find any noticeable change in the number of Fos-LI cells in the lateral geniculate nucleus. This is the area from where PGO waves are most easily recorded in the cat and these waves are present immediately before and during REM sleep. PGO waves are hypothesized to be triggered by PGO-burst ncurons and other PGO-related neurons in the LDT-PPT (McCarley et al., 1978; Steriade et al., 1990b). In our study, the presence of PGO waves was used to confirm REMc and these waves were elicited whenever REMc occurred. Therefore, it is interesting that even when PGO waves were present with 2 hr long REMc bouts, the LGN failed to show Fos-LI cells above basal levels. Other thalamic sites also subserve REM sleep-related functions such as medi-

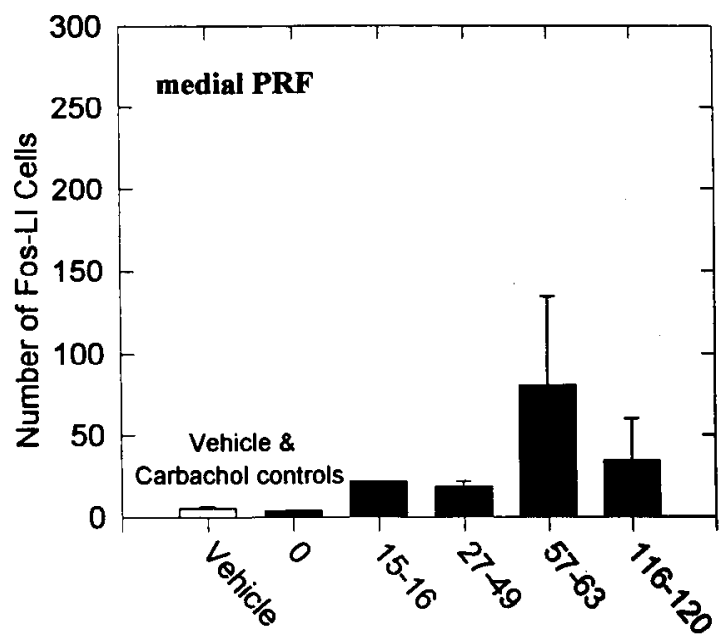

Duration of REMc (range in minutes)

Figure 7. Number of Fos-LI cells in the medial PRF in response to REMc. The data represents counts of Fos-LI cells from the side contralateral to the microinjection side. There was a significant effect related to REMc $(p<0.05)$, but because of high variability pairwise comparisons showed no significant difference. ating the cortical desynchronization that occurs during waking and REM sleep (Steriade et al., 1990a). We found that Fos-LI was always present in various thalamic areas, such as the dorsomedial, central, and ventrobasal areas. The medial habenula also contained high numbers of Fos-LI regardless of treatment. Similarly, the visual cortical layers did not show a change in Fos-LI, which could be attributed to REMc.

\section{Discussion}

In the present study, we examined for the first time the time course of Fos-LI in discrete pontine nuclei in response to varying durations of REMc, and we have also controlled for the effects of carbachol microinjections. These findings are necessary in order to understand the transcriptional process during natural sleep. Compared to vehicle or carbachol controls, animals with REMc had a significantly higher number of Fos-LI cells in discrete pontine regions implicated in REM sleep generation. More Fos-LI cells were seen with $1 \mathrm{hr}$ long REMc bouts compared to shorter or longer REMc bouts.

In this study, cholinergic stimulation was used to trigger REMc. Cholinergic drugs have been shown to rapidly induce a state that resembles REM sleep in rats, cats, dogs, and humans (reviewed in Shiromani et al., 1987). In cats, microinjections of carbachol, a mixed cholinergic agonist, into the medial PRF trigger REM sleep (George et al., 1964; Baghdoyan et al., 1987). The drug-induced REM sleep is similar in many respects to normal REM sleep in terms of cardiovascular changes (Shiromani et al., 1986; Lydic et al., 1989) and acetylcholine (ACh) release (Lydic et al., 1991). The motoneuron inhibition responsible for the atonia of REM sleep is similar during REMc and physiological REM sleep (Morales et al., 1987). Putative serotonergic cells are silent during REMc just like in physiological REM sleep (Steinfels et al., 1983), and the change in activity of medial PRF neurons has been shown to be temporally related to the emergence of the carbachol-induced REM sleep (Shiromani et al., 1986). Greene et al. (1989) used the in vitro pontine slice preparation to show that a majority of medial PRF neurons respond- 
ed to carbachol and the membrane depolarization was similar to that obtained during physiological REM sleep (Ito et al., 1984).

In the present study, cholinergic stimulation alone was not sufficient to induce Fos-LI. For instance, the effects of carbachol in inducing REMc and Fos-LI were confined to the medial PRF. Microinjection of carbachol outside the medial PRF area, or injections of a lower dose of carbachol into the medial PRF, did not trigger REMc and the number of Fos-LI cells were statistically comparable to vehicle controls. These findings agree with recent data which showed that in the suprachiasmatic nucleus microinjection of carbachol was not sufficient by itself to trigger Fos-LI (Colwell et al., 1993). Thus, it is clear that in the present study, changes in Fos-LI were not simply the result of carbachol administration but also dependent on the elicitation of an REMlike state.

We found increased numbers of Fos-LI cells in the LDT, PPT, LC, dorsal raphe, and the medial PRF (counting the side contralateral to the microinjection). These areas are distant from the carbachol microinjection sites, implying transynaptic effects leading to $c$-fos expression. Moreover, diffusion of the drug cannot explain the effects because Fos-LI cells were found to be equally distributed in monoaminergic and cholinergic regions ipsilateral and contralateral to the microinjection site. Neurons in the LDT, PPT, LC, dorsal raphe, and medial PRF have been implicated in producing REM sleep, and both intracellular and extracellular unit studies have shown that these neurons exhibit marked changes in firing rates in relation to REM sleep (Steriade and McCarley, 1990). The presence of Fos-I I in these areas suggests coordinated changes in a network underlying REMc. The viability of such a network in evoking REMc and Fos-LI is further confirmed by our finding that stimulation by carbachol of neurons outside this network did not evoke REMc or Fos-LI.

The intracellular mechanism leading to c-fos expression in the LDT, PPT, LC, dorsal raphe, and medial PRF is unclear at this time. However, NMDA-mediated calcium entry might be involved because recent evidence shows a strong role of glutaminergic pathways in evoking REM sleep components (Lai et al., 1991). Transcription of the $c$-fos gene has been shown to occur in response to increases in cAMP or calcium which phosphorylate a cAMP/calcium response element binding protein (CREB) (Sheng et al., 1990, 1991). However, phosphorylation of CREB might be only onc of the cvents lcading to $c$-fos transcription (Shiromani et al., 1994).

Increased numbers of Fos-LI cells were found in the LDT compared to the other pontine groups. The LDT along with the adjoining PPT area contains cholinergic cells, and these cells are considered prime candidates for orchestrating the various neuronal elements related to the REM sleep process (reviewed in Shiromani et al., 1988). The higher number of Fos-LI cells in the LDT suggests a greater participation of cells in this neuronal group in the REMc process. A subpopulation of cells in the LDT have been found to increase discharge selectively during REM sleep (Steriade et al., 1990; Kayama et al., 1992). However, the temporal change in Fos-LI in the LDT in response to REMc was similar to the other pontine neuronal populations. This further suggests that there is a synchronized interplay between various neuronal populations in orchestrating the REMc process. The role of a subpopulation of LDT-PPT cholinergic neurons in the REM sleep process is further supported by our preliminary analysis, which has revealed that some of the cholinergic cells are also Fos-LI positive (Shiromani et al., work in progress).

Interestingly, in the present study, increased numbers of Fos-
LI cells were found in the LC and dorsal raphe where neuronal activity typically ceases during normal REM sleep (Hobson et al., 1975; McGinty and Harper, 1976). Putative serotonergic neurons are also silent during REMc (Steinfels et al., 1983). However, I.ydic et al. have found high metabolic activity in these areas in conjunction with normal REM sleep (Lydic et al., 1991). We suggest that these effects might be representative of increased discharge of GABA interneurons. Increased release of GABA as measured by microdialysis has been noted during natural REM sleep in the dorsal raphe (Nitz et al., 1993).

In this study we found that Fos-LI was related to the duration of REMc; maximal numbers of Fos-LI cells were found with 1 hr continuous REMc compared with shorter and longer REMc bouts. Previously, Shiromani and McGinty (1986) noted that the activity of medial PRF and other pontine neurons was temporally related to the emergence and decline of REMc. We have now shown that transcriptional coding in discrete pontine neurons is also temporally related to the duration of REMc. Perhaps c-fos expression is turned off once neuronal activity reaches critical levels. However, more sophisticated techniques that focus on mRNA levels will be needed to fully understand the temporal relationship between $c$-fos transcription and REM sleep.

The presence of Fos-LI in populations of REM sleep effector neurons could provide clues about the functional relevance of the REM sleep state. For instance, it has been suggested that transcription factors such as Fos can modify the response of the neuron to subsequent input (Sheng and Greenberg, 1990). Therefore, it is possible that such transcriptional cascades, in pools of neurons, might code for intracellular events that reset the "need" for REM sleep, maintain synaptic efficacy and homeostasis in neuronal clusters, or, in the young, promote growth and development. Previously, before IEG expression was known, various investigators had suggested similar functions for REM sleep (see Webb, 1981).

\section{References}

Baghdoyan HA, Rodrigo-Angula ML, McCarley RW, Hobson JA (1984) Site-specific enhancement and suppression of desynchronized sleep signs following cholinergic stimulation of three brainstem sites. Brain Res 306:39-52.

Baghdoyan HA, Rodrigo-Angulo ML, McCarley RW, Hobson JA (1987) $\Lambda$ neuroanatomical gradient in the pontine tegmentum for the cholinoceptive induction of desynchronized sleep signs. Brain Res 414:245-261.

Berman AL (1968) In: The brainstem of the cat. Madison, WI: University of Wisconsin.

Chiu R, Boyle WJ, Meek J, Smeal T, Hunter T, Karin M (1988) The c-fos protein interacts with c-jun/AP-1 to stimulate transcription of AP-1 responsive elements. Cell 54:541-552.

Colwell CS, Kaufman CM, Menaker M (1993) Phase-shifting mechanisms in the mammalian circadian system: new light on the carbachol paradox. J Neurosci 13:1454-1459.

El Mansari M, Sakai K, Jouvet M (1989) Unitary characteristics of presumptive cholinergic tegmental neurons during the sleep-waking cycle in freely moving cats. Exp Brain Res 76:519-529.

Franza BR, Rauscher FJ, Josephs SF, Curran T (1988) The Fos complex and Fos-related antigens recognize sequence elements that contain AP-1 binding sites. Science 239:1150-1153.

Gentz R, Rauscher FJ, Abate C, Curran T (1989) Parallel association of Fos and Jun leucine zippers juxtaposes DNA binding domains. Science 243:1695-1699.

George R, Haslett WL, Jenden DJ (1964) A cholinergic mechanism in the pontine reticular formation: induction of paradoxical sleep. J Neuropharmacol 3:541-552.

Giovannelli L, Shiromani PJ, Jirikowski GF, Bloom FE (1992) Expression of c-fos protein by immunohistochemically identified oxy- 
tocin neurons in the rat hypothalamus upon osmotic stimulation. Brain Res 588:41-48.

Greene RW, Gerber U, McCarley RW (1989) Cholinergic activation of medial pontine reticular formation neurons in vitro. Brain Res 476: 154-159.

Hobson JA, McCarley RW, Wyzinski PW (1975) Sleep cycle oscillation: reciprocal discharge by two brainstem neuronal groups. Science 189:55-58.

Ito K, McCarley RW (1984) Alterations in membrane potential and excitability of cat medial pontine reticular formation neurons during changes in naturally occurring sleep-wake states. Brain Res 292:169175 .

Kayama Y, Ohta M, Jodo E (1992) Firing of "possibly" cholinergic neurons in the rat laterodorsal tegmental nucleus during sleep and wakefulness. Brain Res 569:210-220.

Lai YY, Siegel JM (1991) Pontomedullary glutamate receptors mediating locomotion and muscle tone suppression. J Neurosci 11:29312937.

Landschulz WH, Johnson PF, McKnight SL (1988) The leucine zipper: a hypothetical structure common to a new class of DNA binding proteins. Science 240:1759-1/64.

Lydic R, Baghdoyan HA, Zwillich CW (1989) State-dependent hypotonia in posterior cricoarytenoid muscles of the larynx caused by cholinoceptive reticular mechanisms. FASEB J 3:1625-1631.

Lydic R, Baghdoyan HA, Hibbard L, Bonyak EV, DeJoseph MR, Hawkins RA (1991a) Regional brain glucose metabolism is altered during rapid eye movement sleep in the cat: a preliminary study. J Comp Neurol 304:517-529.

Lydic R, Baghdoyan HA, Lorine Z (1991b) Microdialysis of cat pons reveals enhanced acetylcholine release during state-dependent respiratory depression. Am J Physiol 261:R766-R770.

McCarley RW, Nelson JP, Hobson JA (1978) Ponto-geniculo-occipital (PGO) burst neurons: correlative evidence for neuronal generators of PGO waves. Science 201:269-272.

McGinty DJ, Harper RM (1976) Dorsal raphe neurons: depression of firing during sleep in cats. Brain Res 101:569-575.

Merchant-Nancy H, Vázquez J, Aguilar-Roblero R, Drucker-Colín R (1992) c-fos proto-oncogene changes in relation to REM sleep duration. Brain Res 579:342-346.

Morales FR, Engelhardt JK, Soja PJ, Pereda AE, Chase MH (1987) Motoneuron properties during motor inhibition produced by microinjection of carbachol into the pontine reticular formation of the decerebrate cal. J Neurophysiol 57:1118-1129.

Morgan JI, Curran T (1989) Stimulus-transcription coupling in neurons: role of cellular immediate-early genes. Trends Neurosci 12:459462.

Nitz D, Siegel J (1993) Inhibitory amino acid neurotransmission in the dorsal raphe nucleus during sleep-wake cycle. Soc Neurosci Abstr 19:1815.

Sagar SM, Sharp FR (1991) Early response genes as markers of neuronal activity and growth factor action. In: Advances in neurology (Seil FJ, ed), pp 273-284. New York: Raven.

Sheng M, Greenberg ME (1990) The regulation and function of c-fos and other immediate early genes in the nervous system. Neuron 4:477-485.
Sheng M, Dougan ST, McFadden G, Greenberg ME (1990) Membrane depolarization and calcium induce c-fos transcription via phosphorylation of transcription factor CREB. Neuron 4:571-582.

Sheng M, Thompson AM, Grecnberg EM (1991) CREB: a Ca ${ }^{2+}$-regulated transcription factor phosphorylated by calmodulin-dependent kinases. Science 252:1427-1430.

Shiromani P, McGinty DJ (1986) Pontine neuronal response to local cholinergic microinfusion: relation to REM sleep. Brain Res 386:2031.

Shiromani P, Siegel JM, Tomaszewski K, McGinty DJ (1986) Alterations in blood pressure and REM sleep after pontine carbachol microinfusion. Exp Neurol 91:285-292.

Shiromani P, Gillin JC, Henriksen SJ (1987) Acetylcholine and the regulation of REM sleep: basic mechanisms and clinical implication for affective illness and narcolepsy. Annu Rev Pharmacol Toxicol 27: $137-156$.

Shiromani PJ, Armstrong DM, Berkowitz A, Jeste DV, Gillin JC (1988) Distribution of choline acetyltransferase immunoreactive somata in the feline brainstem: implications for REM sleep generation. Sleep $11: 1-16$.

Shiromani PJ, Malik MM, McCarley RW (1992) Topographical distribution of noradrenergic, serotonergic and cholinergic perikarya in the feline pons: a 3-D perspective. Sleep Res 21:77.

Shiromani PJ, Kilduff TS, Bloom FE, McCarley RW (1992) Cholinergically induced REM sleep triggers Fos-like immunoreactivity in dorsolateral pontine regions associated with REM sleep. Brain Res 580:351-357.

Shiromani PJ, Magner M, Winston S, Charness ME (1995) Time course of phosphorylated CREB and Fos-like immunoreactivity in the hypothalamic supraoptic nucleus after salt loading. Mol Brain Res, in press.

Steinfels GF, Heym J, Strecker RE, Jacobs RI, (1983) Raphe unit activity in freely moving cats is altered by manipulations of central but not peripheral motor systems. Brain Res 279:77-84.

Steriade M, McCarley RW (1990) Brainstem control of wakefulness and sleep. New York: Plenum.

Steriade M, Datta S, Paré D, Oakson G, Curró Dossi R (1990a) Neuronal activities in brain-stem cholinergic nuclei related to tonic activation processes in thalamocortical systems. J Neurosci 10:25412559.

Steriade M, Paré D, Datta S, Oakson G, Curró Dossi R (1990b) Different cellular types in mesopontine cholinergic nuclei related to ponto-geniculo-occipital waves. J Neurosci 10:2560-2579.

Turner R, Tjian R (1989) Leucine repeats and an adjacent DNA binding domain mediate the formation of functional cFos-cJun heterodimers. Science 243:1689-1694.

Velazquez-Moctezuma J, Gillin JC, Shiromani PJ (1989) Effect of specific M1,M2 muscarinic receptor agonists on REM sleep generation. Brain Res 503:128-131.

Webb WB (1981) Some theories about sleep and their clinical implications. Psychiatr Ann 11:415-422.

Winson J (1972) Interspecies differences in the occurrence of theta. Behav Biol 7:479-487.

Yamuy J, Mancillas JR, Morales FR, Chase MH (1993) C-fos expression in the pons and medulla of the cat during carbachol-induced active sleep. J Neurosci 13:2703-2718. 